AL-TA'LIM JOURNAL, 23 (2), 2016, (169-174)

(Print ISSN 1410-7546 Online ISSN 2355-7893)

Available online at http://journal.tarbiyahiainib.ac.id/index.php/attalim

\title{
The Effect of Jigsaw towards Third Year Students' Learning Interest in IAIN Bukittinggi
}

\author{
Received: 02 ${ }^{\text {th }}$ April 2016; Revised: 04 $4^{\text {th }}$ April 2016; Accepted: $10^{\text {th }}$ July 2016
}

Permalink/DOI: http://dx.doi.org/10.15548/jt.v23i2.231

\author{
Hasna Wati \\ Institut Agama Islam Negeri Bukittinggi, \\ West Sumatra, Indonesia \\ Email: hasna.stain@gmail.com
}

\begin{abstract}
This research aims to determine: 1). The implementation of Jigsaw in test and evaluation course for third semester students of Islamic education department in IAIN Bukittinggi; 2). The types of students' learning interest in test and evaluation course; and 3). The effect of Jigsaw towards students' learning interest at Islamic education department in IAIN Bukittinggi. This research was conducted through survey method using regression analysis with one predictor. The total population in this research is 353 students in which $11.9 \%$ of them is taken as sample (42 students). The data were collected through questionnaire, documentation, and observation. The findings of the study showed that: 1). Jigsaw is in the "average" category with the mean score 66 in 65-67 interval; 2). Third semester students' learning interest of Islamic education department in IAIN Bukittinggi is in "average" category with the mean score of 65.95 in 65-67 interval; and 3). There is a positive effect of Jigsaw towards learning interest in test and evaluation course for third semester students of Islamic education department in IAIN Bukittinggi, which is demonstrated from the statistical analysis $\mathrm{r}_{\mathrm{xy}}=0.6365$ while from hypothesis testing by simple regression analysis, it is obtained that $\mathrm{Y}=0.5182 \mathrm{X}+31.3701$. it is concluded that there is significant effect of Jigsaw towards students' learning interest in test and evaluation course for third semester students of Islamic education major in IAIN Bukittinggi.
\end{abstract}

Keywords : Learning interest, Jigsaw, test and evaluation course.

How to Cite: Hasnawati. (2016). The Effect of Jigsaw towards third year students' learning interest in IAIN Bukittinggi. Al-Ta Lim Journal, 23(2) doi:http://dx.doi.org/10.15548/jt.v23i2.231

\section{INTRODUCTION}

Learning is a process that a person experience to accomplish expected change in his behavior as the result of both his observation and his interaction with the environment. Through learning process, students can improve his or her individual quality, which improves their behavior and benefits for their future life. However, learning can be solely seen as the goal, but it is the process to achieve that goal. Therefore, learning can be active and integrative using various forms of activities to obtain the expected goal, the whole human activities and achievement can be considered as the result of learning process.

Based on preliminary study, it was found that the students in the Department of 
Islamic Education at IAIN Bukittinggi paid less attention to the learning of test and evaluation course. They preferred spending their time to play or watch than to study. Accordingly, their interest in learning is decreasing or even they have no interest in learning at all. In classroom management, students who just keep silent during the class without showing disruptive behaviour can not be considered to pay their attention fully to the learning process. Hence, the lecturers need to be aware that some student might not absorb the whole topics covered in the lecturers' explanation, so to ease the learning process; the students must have the interest in learning. They should be also taught using cooperative learning model.

Students' interest can be expressed through preferential statements, in which students like certain things better than the others. It can also be manifested through involvement in a certain activity. This interest is not genetically inherited or innate, but it is acquired in the personal development process.

In general, researchers refer now to the concept of interest with the following ideas: firstly, interest emerges from an individual's interaction with his or her environment; secondly, interest is characterized by affective as well as cogitive components (Krapp, 1999).

Within the interest literature, the relationship between interest and learning has focused on three types of interest: individual, situational, and topic. Individual interest is considered to be an individual's predisposition to attend to certain stimuli, events, and objects. Situational interest is elicited by certain aspects of the environment. These include content features such as the ways in which tasks are organized and presented. Topic interest, the level of interest triggered when a speciffic topic is presentd, seems to have both individdual and situational aspects (Ainley, Hidi, \& Berndorff, 2002).

The literature has shown that individual interest is an important if not a critical factor of academic motivation and learning. Children as well as adults who have individual interests in activities or topics focus their attention, persist for longer periods of time, and enjoy their engagements more, are more likely to use strategic processing and tend to learn and write better than those without such interests (Hidi, 2001).

Meanwhile, Cooperative learning is the learning model used by grouping system or small team, involving four to six students with the different backgrounds. In solving the given group task, the students must work cooperatively and rely on each other to comprehend the learning topics. It is conducted in order to raise students' learning participation, to facilitate them to experience leadership attitude and decision making, and to enable them to share with the different backgrounds. It is a set of practical classroom techniques that can be applied by the lecturers to help students seriously learn in every course, from basic understanding until solving complex problem. In this learning model, students work collaboratively in the small group where they can help and rely on each other.

Slavin (1980) proposed some components of cooperative learning. First is positive interdependence which works or activities heavily depends on the effort of each group member. To form an effective team work, teachers need to arrange the learning task in such a way that each group member is required to finish the task on his own, so the others can achieve the goal. In addition, the group must be encourage to share the task equally among the members based on each own capability. This is the nature of positive interdependence, which means the group will fail to finish the learning task if some members do not finish the given task assigned to them. Hence, each member must contribute to the group and the cooperation is expected from each of them.

Second is individual responsibility where the components of cooperative learning come up as the result of the first one. If the 
task and the group assessment are conducted in accordance to cooperative learning procedure, every student will feel responsible enough to give their best in finishing the task. The main key for this group work method is lecturers' preparation in the learning task arrangement.

Third is interaction where every group must be given an opportunity to interact and discuss among each member. As old folks say, two heads are better than one. Hence, the works of some people will be much better than the other one. Furthermore, the result of group work will be better than that of each group member. It must allow each group member to interact, to share, and to learn from each other. Interaction will enable each group member to have valuable experience in working together, valuing differences, and relying on each other. The goal of cooperative learning is to give students knowledge, concept, ability, and understanding that they need foe their future contribution to the society. It also creates circumstance in which individual achievement is influenced by the group achievement. Cooperative learning is developed to achieve at least three most important learning objectives: academic achievement, individual acceptance, and social skill development.

Fourth is academic achievement where the goal of cooperative learning does not only encompass various social goals but also improve students' achievement and their academic task. Some experts propose that this model can significantly assist students in understanding difficult concept. The proponents of this model have shown that cooperative learning can improve students' score in academic achievement and create norm changes related to learning outcome. Another objective of this model is external acceptance obtained from various people from different backgrounds, races, cultures, social class, and ability. Cooperative learning can provide students from various backgrounds with the opportunity to work cooperatively and value each other's differences.

Fifth is development of social skills. This component requires students to be provided with various social skills such as tolerance, good-manner, and presenting their ideas. It also provides students with other useful skills for example leadership, communicative skill, and problem solving. These whole skills are presented to interact interpersonally.

Although the basic principles of cooperative learning do not change, some variations of this model are to be found. There are four approaches that can be used in implementing this model namely, STAD, Jigsaw, Teams Games Tournaments, and structural approaches encompassing Think Pair Share (TPS) and Numbered Head Together (NHT).

Jigsaw was developed and tested by Aronson (1978) in Texas University as well as his friends in John Hopkins University. Jigsaw is cooperative learning model involving small group that contains of 4-6 members. The topic taught to the students can be in the form of text in which each member is responsible to finish it. This model is designed to improve students' responsibility skill toward their and their peer learning. They do not only learn the given topics but also teach them to their group members. Hence, students are cointerdependent and must work cooperatively to study and comprehend the learning topic given. Two groups are involved in jigsaw cooperative learning model, namely original group and expert group. Original group are the main group composed from several expert groups. Expert group is the member of different original group who is assigned the similar topic and is expected to discuss it collaboratively.

Interest is arising from both external and internal factors. Having interest in certain 
activities can serve as the fundamental need to achieve the goal from the activities mentioned. The rising of interest is influenced by some factors such as strong desire to improve one's life or to get a better jog for happier life. High learning interest tends to allow students to gain good achievement in their learning while low interest leads them to gain low achievement.

\section{METHOD}

This research used survey method with regression analysis. Survey research is the kind of research, which selects some samples from the total population and by using questionnaire as the data collection technique. Regression analysis technique is regression analysis conducted with one predictor and deviation score. This technique is used to find the information about correlational level between criterion variable and predictor. The instrument of this research is questionnaire, using with Likert Scale, with 20 questions items about the implementation of Jigsaw and 20 questions about students' learning interest in test and evaluation course, which consist of both positive and negative questions. In this research, the researcher also conducted non-participant observation, in which the researcher sat at the back of the classroom observing learning activities and process in test and evaluation course.

\section{RESULT AND DISCUSSION}

Students feel happy when the teacher implemented Jigsaw because they can help and depend on each other when solving the tasks the lecturer gave them. Hence, this learning model will nurture the togetherness among the students. This present finding is in line with Ibrahim, et.al who claims that cooperative learning model is not only useful to help students understand complex learning concepts but also useful to for students to interact with their peer.

From the statistical analysis, it is known that the variable of jigsaw in in test and evaluation course at IAIN Bukittinggi is in "average" category, frequency of $40.5 \%$ within the interval of 65-67. On the other hand, the variable of learning interest of third semester student of islamic education major in IAIN in Bukittinggi is in "average" category, frequency of $16.7 \%$ within the interval of 65-67. Based on hypothesis testing using simple regression analysis, it is obtained the regression equation $\mathrm{Y}=0.5182 \mathrm{X}+$ 31.3701 while to test the significant of regression analysis the researcher uses variant analysis for regression.

Based on the calculation, it is obtained that $\mathrm{F}_{\text {count }}=27.2373>\mathrm{F}$ table for significance level of $5 \%$ is 4.08 while for significance level $1 \%$ is 7.31 . Since $F$ hitung $>$ than $F$ table, it can be concluded that the regression equation is significant. From this calculation, null hypothesis (Ho) Jigsaw does not affect learning interest in test and evaluation course for third semester students of Islamic education major in IAIN Bukittinggi" is rejected. On the other hand, alternate hypothesis (Ha) "jigsaw cooperative learning model affects learning interest in test and evaluation course for third semester students of Islamic education department in IAIN Bukittinggi" is accepted. The positive effect jigsaw towards learning interest in test and evaluation course is $0.6365,0.304$ in significance level of $5 \%$ and 0.393 in significance level of $1 \%$. Since rxy $>\mathrm{rt}$, where the result is in significant level. Thus, It can be concluded that jigsaw cooperative learning model has positive effect toward learning interest in test and evaluation course for third semester students of Islamic education major in IAIN Bukittinggi.

The data taken from observation showed that the teaching and learning process of test and evaluation course at third semester students at Islamic education in IAIN Bukittinggi by using Jigsaw can stimulate students to learn. For example, before dividing the lesson material that will be given the teacher introduces the material that will be discussed on that day, professors post the topics on the board and ask what the students know about the matter, with the aim of 
schemata enable students to be better prepared to face the new study material. Then, lecturers divide students into groups of heterogeneous group, a student learn about the test and non test, other students learn how to create a table of specifications matter; other students learn how to create a lattice matter and the other students again study the manufacture of about opinions and essays. Members of the other group are in charge of the same topics together in a group of experts, to discuss and work on their part. Upon completion the students back to the original group to teach about the part that is read and done to his friends. In the discussion the students were keen to exchange information with their friends, and they are also happy because they can learn together to assist each other in completing the tasks given from the lecturer. Then the activity concludes with a discussion with all the students on the topic of the day's lesson and each student will receive a test on every topic.

Jigsaw is a cooperative learning model which allows the students to be involved actively in its process since in this learning model they are required to take responsibility towards the learning material given to them. They are expected to explore deeply and to solve the problems they encounter in the learning process. By using this learning model, teacher can enable students to learn well, both students with low achievement and students with good achievement. It can be seen as the initial step to raise students' learning interest.

Interest can be formed from external factors, one of which is jigsaw cooperative learning model that will develop the interest needed. Therefore, it can be concluded that jigsaw cooperative learning model can raise students' interest in learning. It can be proved when the lecturer wrote the topic on the whiteboard and invited students to share with the class what they had known about the topic. It is done to activate students' background knowledge before learning the new topic. It proved the research conducted by Mahpuroh (2007).

Learning with jigsaw, students will enjoy the learning process because they can help each other and work together in solving the tasks given. Accordingly, this learning model will build togetherness among the students. This is in line with Nur (2005) who claims that cooperative learning model is not only useful to help students understand complex learning concepts but also useful for students interact with their peer.

\section{CONCLUSION AND RECOMMENDATION}

Based on the research findings, it can be concluded that Jigsaw is a learning cooperative learning model that provides opportunities for all students to be actively involved in the process of thinking and learning, because in Jigsaw, every student should be responsible for the material provided, the student must find and resolve the problems it faces, By using Jigsaw it can stimulate students to learn, both from students and student groups under the top group. It shows as a first step the interest of student learning. Interests can be formed from external factors one of which is the jigsaw that will build on that interest. It can be concluded that the cooperative learning model Jigsaw can foster student interest in learning.

The lecturer should consider the implementation of jigsaw as an alternative technique in teaching test and evaluation course. He or she is suggested to use this cooperative learning model for carrying out further test and evaluation course in improving the students' ability. The finding of this research hopefully can be the beneficial reference for the next investigator in conducting the better research next time. 


\section{REFERENCES}

Ainley, M., Hidi, S., \& Berndorff, D. (2002). Interest, learning, and the psychological processes that mediate their relationship. Journal of Educational Psychology, 94(3), 545.

Aronson, E., \& others. (1978). The jigsaw classroom. Sage.

Hidi, S. (2001). Interest, reading, and learning: Theoretical and practical considerations. Educational Psychology Review, 13(3), 191-209.

Krapp, A. (1999). Interest, motivation and learning: An educationalpsychological perspective. European Journal of Psychology of Education, 14(1), 23-40.
Mahpuroh. (2007). Meningkatkan Aktivitas Belajar Siswa Pada Kelas VIIA Melalui Pembelajaran kooperatif Jigsaw Pada Pokok Bahasan Keanekaragaman Makhluk Hidup MTs Assalam Kejene Tahun Pelajaran 2007/2008 (thesis). IKIP PGRI Semarang, Semarang.

Nur, M. (2005). Pembelajaran Kooperatif. Surabaya: Unesa.

Slavin, R. E. (1980). Cooperative learning. Review of Educational Research, 50(2), 315-342. 